\title{
Skeletal Depletion in Hens Laying on a Low-calcium Diet
}

\author{
By T. G. TAYLOR AND J. H. MOORE \\ Department of Agricultural Chemistry, University of Reading
}

(Received 5 October 1953)

It is generally accepted that the skeletons of birds and mammals act as a reservoir of minerals, in particular calcium and phosphorus, which can be drawn upon when dietary sources are inadequate for requirements. In birds these bone reserves are especially important during the egg-laying period. In the laying hen the rate of calcium deposition in the shell is often greater than the rate of absorption from the intestine, even when the calcium level of the diet conforms to accepted standards for egg production (Tyler, I940). The immediate source of the additional mineral is thought to be the medullary bone contained in the marrow cavities of the long bones of the legs (Kyes \& Potter, r934; Bloom, Bloom \& McLean, I94I; Bloom \& Domm, r94I) and in other parts of the skeleton (Taylor \& Moore, I953). This highly specialized bone undergoes rapid changes during the egg-laying cycle, periods of intense bone formation alternating with periods of equally intense bone destruction (Bloom et al. I94I) and in birds that are in calcium balance the mineral reserves lost during the period of shell calcification are restored when active shell formation is not taking place. On a low-calcium diet the minerals for the calcification of the newly formed medullary bone are derived from structural bone (Benoit \& Clavert, 1945), which becomes progressively depleted, and presumably a similar state of affairs exists in birds that are in negative calcium balance, even though their ration supplies theoretically adequate amounts of calcium (Morgan, Mitchell, Ringrose \& Lease, 1942).

There is a limit to the amount of mineral matter that can be supplied by the skeleton, and as this limit is approached the egg-shells beome progressively thinner, until eventually soft-shelled eggs are laid (Common, 1938) or laying ceases altogether (Deobald, Lease, Hart \& Halpin, I936). Common (I938) has shown that $24 \%$ of the total body calcium of hens laying on a low-calcium diet can be withdrawn from the skeleton for shell formation, but the extent to which individual bones are depleted under these conditions does not appear to have been studied, and this is one of the objects of the present experiment. A second object of study is the effect of calcium depletion on the minerals of both cortical and medullary bone.

\section{The birds and their treatment}

\section{EXPERIMENTAL}

Eight Light Sussex pullets of the same strain, judged as being due to lay in about a month, were placed in separate metabolism cages on I $_{5}$ October $195^{2}$. Their daily ration consisted of $100 \mathrm{~g}$ basal meal to which were added $5.5 \mathrm{~g}$ calcium carbonate and $2 \mathrm{ml}$. cod-liver oil. This mixture was made into a crumbly mash with $80 \mathrm{ml}$. of a 
solution containing $0.5 \%(\mathrm{w} / \mathrm{v}) \mathrm{NaCl}$ and $0.0125 \%(\mathrm{w} / \mathrm{v}) \mathrm{MnSO}_{4} .4 \mathrm{H}_{2} \mathrm{O}$. After $\mathrm{I}$ week the daily meal allowance was increased to I $\mathrm{rO} \mathrm{g} / \mathrm{bird}$, and this level of feeding was maintained throughout the rest of the experiment. (The birds were also given radioactive calcium and phosphorus and the experimental results concerning these radioactive elements will be reported elsewhere.) The basal meal was designed to be as low in $\mathrm{Ca}$ as possible, and its composition in parts by weight was as follows: maize 60 , middlings 15 , bran 10, groundnut meal 1o and dried yeast 10. The meal as fed contained $15.7 \%$ crude protein, $0.054 \% \mathrm{Ca}$ and $0.546 \% \mathrm{P}$. After a $48 \mathrm{~h}$ preliminary period weekly collections of droppings were made and these continued until laying began, after which droppings were collected daily. Drinking water (distilled) was supplied ad lib. but no grit was given.

After they had laid three eggs on the normal-calcium ration, six of the birds were given a low-Ca diet by withholding the supplement of calcium carbonate from the standard ration. The other two birds, which were to act as controls, were killed immediately after laying their third egg on the normal-Ca ration. Of the remaining birds, two were allowed to lay two eggs, two four eggs, and two six eggs on the low-Ca

Table I. Days on the low-calcium diet, initial and final live weights and final weights of the dry fat-free skeletons of the experimental birds

Bird no.

No. of eggs laid on the low-Ca diet

Days on the low-Ca diet

Initial live weight $(g)$

Final live weight $(\mathrm{g})$

I

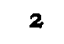

6

IO
2359

2415

Final weight of dry fat-free 69.52

skeleton (g)

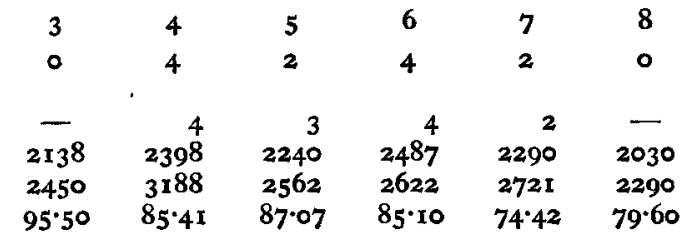

ration, and all were killed immediately after the required number of eggs had been laid. All eggs were recovered intact with the exception of the final ones laid by the six-egg birds. The shells of these eggs were thin and the birds began to eat them, but they were recovered from the crop and gizzard for analysis within a few minutes. The experimental lay-out, together with initial and final live weights and dry fat-free skeleton weights, are summarized in Table $\mathbf{I}$.

\section{Preparation of bone for analysis}

Each bird was skinned and eviscerated after it was killed, and as much muscular tissue as could be dissected from the carcass was removed. The skeleton was completely freed from soft tissue by heating it gently in liquid paraffin for $5^{-6} \mathrm{~h}$ during which time the temperature did not rise above $100^{\circ}$. The individual bones were then placed on filter-paper in an oven at 100-105 and subsequently extracted with a boiling alcohol-benzene mixture $(2: \mathrm{I}, \mathrm{v} / \mathrm{v})$ for $24 \mathrm{~h}$ in a Soxhlet apparatus. They were then dried in the oven, cooled in a desiccator and weighed. The manner in which the skeleton was divided for weighing and for subsequent analysis is shown in Table 4 .

The medullary bone was then separated from the structural bone. This was readily achieved with the tibia, femur, radius, ulna, coracoid and scapula by splitting the bone and scraping out the fine powdery medullary bone from the marrow cavity. 
Other bones were first ground in a Wiley mill using a 20-mesh sieve, and the medullary was separated from the cortical bone by means of a $300-$ mesh sieve. With some samples it was necessary to grind gently in a small mortar after milling, as not all the medullary bone was fine enough to pass the 300-mesh sieve without this additional treatment. Using these techniques it was possible to achieve a fairly complete separation of the two types of bone as judged by appearance. Before analysis the cortical and scraped medullary-bone samples were also ground to pass a 300-mesh sieve.

\section{Preliminary treatment of materials}

Droppings, egg contents and egg-shells were subjected to a nitric acid-perchloric acid digestion by the method of Gerritz (1935) before the determination of calcium and phosphorus. Droppings were first dried in an oven at $100-105^{\circ}$ for $24 \mathrm{~h}$ and then ground in the laboratory mill. Weighed samples of egg contents were taken for digestion after mixing them in a Waring Blendor. The complete shells were digested separately.

Weighed samples of dry 300 -mesh bone were ashed at $600^{\circ}$ in an electric muffle furnace for $24 \mathrm{~h}$ and, after weighing, the ash was dissolved in $\mathrm{N}$-nitric acid.

\section{Analytical methods}

Calcium. Determinations on droppings and egg-shell digests were made by precipitation as oxalate and titration with permanganate, and on egg contents by the semimicro method of Wheatley (1944). The $\mathrm{Ca}$ of bone-ash solutions was precipitated as oxalate in $15 \mathrm{ml}$. centrifuge tubes and, after washing, the precipitate was dissolved in $2 \mathrm{ml}$. $0.1 \mathrm{~N}$-ceric sulphate, the excess being titrated with $0.025 \mathrm{~N}$-ferrous sulphate using $o$-phenanthrolene ferrous complex as indicator.

Phosphorus. Phosphorus was determined by the colorimetric method of Koenig \& Johnson (1942) as modified by Kitson \& Mellon (1944) using a Spekker absorptiometer.

\section{RESULTS}

Pre-laying storage of minerals. The retention of $\mathrm{Ca}$ and $\mathrm{P}$ during the $\mathrm{10}$ days or so before laying was calculated from the balance results. The figures are given in Table 2. Birds I and 2 came into lay sooner than expected, and it is probable that pre-laying storage of minerals began before the experimental period, so that the weights recorded represent minimum values. The $\mathrm{Ca}: \mathrm{P}$ ratio of the mineral matter retained during this period varied from 2.93 to 6.79 in individual birds with a mean of 4.25 , figures of the same order as those reported by Common (1936) for pullets fed a ration adequately supplied with calcium.

Egg-shell $\mathrm{Ca}$. The weight of shell $\mathrm{Ca}$ in the eggs laid on the low-Ca ration, together with the same values expressed as a percentage of egg weight, are given in Table 3 . The eggs laid by each bird were lettered in sequence, eggs $A, B$ and $C$ being laid on the normal-Ca diet. In general, there was a reduction in the percentage of shell $\mathrm{Ca}$ immediately the birds were placed on the low-Ca diet, a reduction which became progressively greater with each egg laid. These results are in agreement with those reported by Common (1938).

Skeletal depletion during the low-Ca régime. Since the intake of $\mathrm{Ca}$ and $\mathrm{P}$ and the losses in eggs and droppings were known, the amounts of these elements lost from the 
Table 2. Calcium and phosphorus stored before laying and lost during the low-calcium period, and calculated percentage losses from the skeleton during the low-calcium period

\begin{tabular}{|c|c|c|c|c|c|c|c|c|}
\hline & \multicolumn{8}{|c|}{ No. of eggs laid on low-Ca diet } \\
\hline & \multicolumn{2}{|c|}{0} & \multicolumn{2}{|c|}{2} & \multicolumn{2}{|c|}{4} & \multicolumn{2}{|c|}{6} \\
\hline & $\begin{array}{c}\text { Bird } \\
\text { no. } 3\end{array}$ & $\begin{array}{c}\text { Bird } \\
\text { no. } 8\end{array}$ & $\begin{array}{l}\text { Bird } \\
\text { no. } 5\end{array}$ & $\begin{array}{l}\text { Bird } \\
\text { no. } 7\end{array}$ & $\begin{array}{c}\text { Bird } \\
\text { no. } 4\end{array}$ & $\begin{array}{c}\text { Bird } \\
\text { no. } 6\end{array}$ & $\begin{array}{l}\text { Bird } \\
\text { no. I }\end{array}$ & $\begin{array}{l}\text { Bird } \\
\text { no. } 2\end{array}$ \\
\hline \multicolumn{9}{|l|}{ Information about storage before laying } \\
\hline Storage period (days) & II & 12 & 14 & 15 & Io & 13 & Io & 8 \\
\hline Ca re & $6 \cdot 52$ & 4.90 & $4 \cdot 43$ & $6 \cdot 75$ & $7 \cdot 53$ & $5 \cdot 52$ & $4 \cdot 65$ & $4 \cdot 3 x$ \\
\hline P ret & I.36 & $I \cdot 27$ & I. $5 \mathrm{I}$ & $x \cdot 67$ & $\mathrm{r} 56$ & $0.8 \mathbf{I}$ & $I \cdot I_{4}$ & $r \cdot 16$ \\
\hline $\mathrm{Ca}: \mathrm{P}$ ratio of retained mineral & 4.80 & 3.85 & $2 \cdot 93$ & 4.03 & $4 \cdot 84$ & $6 \cdot 79$ & 4.07 & $3 \cdot 72$ \\
\hline \multicolumn{9}{|l|}{ Ca balance } \\
\hline Total loss of body $\mathrm{Ca}(\mathrm{g})$ & - & - & 3.61 & $3 \cdot 53$ & $6 \cdot 19$ & $6 \cdot 83$ & $9 \cdot 02$ & 8.37 \\
\hline $\begin{array}{l}\text { Ca in skeleton at beginning of low-Ca } \\
\text { period }(\mathrm{g})\end{array}$ & - & - & 23.77 & $20 \cdot 33$ & $25 \cdot 64$ & $26 \cdot 20$ & 23.54 & $21 \cdot 80$ \\
\hline $\mathrm{Ca}$ in skeleton at slaughter $(\mathrm{g})$ & $22 \cdot 54$ & $\mathbf{1 8 \cdot 9 7}$ & $20 \cdot 16$ & $x 6 \cdot 80$ & $19 \cdot 45$ & $19 \cdot 37$ & $14: 52$ & 13.4 \\
\hline \multicolumn{9}{|l|}{ P balance } \\
\hline Total loss of body $\mathbf{P}(\mathrm{g})$ & - & - & $I \cdot 19$ & $x \cdot 63$ & $2 \cdot 35$ & $2 \cdot 47$ & $2 \cdot 67$ & \\
\hline $\begin{array}{l}P \text { in skeleton at beginning of low-Ca } \\
\text { period }(g)^{*}\end{array}$ & - & & 10.89 & $9 \cdot 31$ & $11 \cdot 74$ & $12 \cdot 00$ & $10 \cdot 78$ & \\
\hline$P$ in skeleton at slaughter $(g)$ & $10 \cdot 3 x$ & 8.70 & $9 \cdot 25$ & $7 \cdot 86$ & 8.99 & $9 \cdot 10$ & 6.99 & 5. \\
\hline P lost from skeleton $(\mathrm{g})$ & - & - & I.64 & $I \cdot 45$ & $2 \cdot 75$ & $2 \cdot 90$ & $3 \cdot 79$ & \\
\hline P stored in soft tissues $(\mathrm{g})$ & - & - & 0.45 & -0.18 & 0.40 & 0.43 & $I^{\prime} \cdot 12$ & $I \cdot 03$ \\
\hline Loss of Ca from skeleton (\%) & - & - & $15 \cdot 2$ & 17.4 & $24 \cdot 2$ & 26.1 & $38 \cdot 3$ & $3^{8 \cdot 4}$ \\
\hline Loss of $P$ fron & - & - & I5.I & $15 \cdot 6$ & 23.4 & $24 \cdot I$ & $35 \cdot \mathrm{x}$ & $35 \cdot 7$ \\
\hline $\mathrm{Ca}: \mathrm{P}$ ratio of total loss & - & - & $2 \cdot 20$ & $2 \cdot 44$ & $2 \cdot 25$ & $2 \cdot 36$ & $2 \cdot 38$ & $2 \cdot 35$ \\
\hline
\end{tabular}

* Calculated on the assumption that the $\mathrm{Ca}: \mathrm{P}$ ratios of the skeletons were $2 \cdot 184$, the mean for the control birds.

Table 3. Shell calcium in eggs laid by birds placed on the low-calcium ration, expressed as weight and as a percentage of egg weight
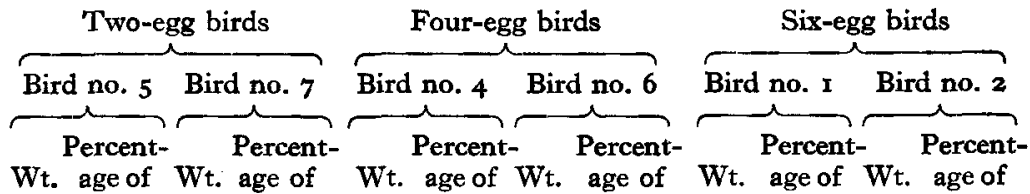

Diet Egg (g) egg wt. (g) egg wt. (g) egg wt. (g) egg wt. (g) egg wt. (g) egg wt.

\begin{tabular}{|c|c|c|c|c|c|c|c|c|c|c|c|c|c|}
\hline Normal-Ca & $\begin{array}{l}A \\
B \\
C\end{array}$ & $\begin{array}{l}1.37 \\
1.66 \\
I \cdot 62\end{array}$ & $\begin{array}{l}3 \cdot 44 \\
4 \cdot 04 \\
3 \cdot 73\end{array}$ & $\begin{array}{l}1 \cdot 56 \\
1 \cdot 71 \\
1.80\end{array}$ & $\begin{array}{l}3.63 \\
3.97 \\
3.91\end{array}$ & $\begin{array}{l}I \cdot 6 I \\
I \cdot 83 \\
I \cdot 85\end{array}$ & $\begin{array}{l}3.53 \\
3.51 \\
3.71\end{array}$ & $\begin{array}{l}I \cdot 68 \\
I \cdot 88 \\
I \cdot 79\end{array}$ & $\begin{array}{l}3 \cdot 33 \\
3 \cdot 83 \\
3 \cdot 4 I\end{array}$ & $\begin{array}{l}I \cdot 60 \\
I \cdot 78 \\
I \cdot 78\end{array}$ & $\begin{array}{l}3 \cdot 48 \\
3.48 \\
3.61\end{array}$ & $\begin{array}{l}I \cdot 54 \\
I .65 \\
I \cdot 84\end{array}$ & $\begin{array}{l}3.54 \\
3.78 \\
3.72\end{array}$ \\
\hline \multirow[t]{6}{*}{ Low-Ca } & $D$ & $x \cdot 68$ & 3.73 & $I^{\circ} 75$ & $3 \cdot 49$ & $I \cdot 56$ & $3 \cdot 29$ & $1 \cdot 75$ & $3 \cdot 28$ & $I \cdot 53$ & $3 \cdot 14$ & $1 \cdot 63$ & 3.61 \\
\hline & $E$ & $1 \cdot 79$ & $3 \cdot 84$ & $1 \cdot 52$ & $3 \cdot 42$ & $I \cdot 73$ & 345 & $I \cdot 66$ & $3 \cdot 16$ & $I \cdot 71$ & $3 \cdot 25$ & $I \cdot 90$ & $2 \cdot 72$ \\
\hline & $\bar{F}$ & - & $\longrightarrow$ & - & - & $\mathrm{I} \cdot 43$ & $2 \cdot 84$ & $I \cdot 6 I$ & 3.10 & $I \cdot 57$ & $3 \cdot 22$ & $I \cdot 47$ & $2 \cdot 97$ \\
\hline & $G$ & - & - & 一 & 一 & $1 \cdot 24$ & $2 \cdot 50$ & 1.57 & $2 \cdot 96$ & $\mathrm{I} \cdot 55$ & $3 \cdot 20$ & $I \cdot 20$ & 2.59 \\
\hline & $H$ & - & 一 & 一 & - & - & - & - & - & $I \cdot 35$ & $2 \cdot 52$ & 0.99 & $x \cdot 99$ \\
\hline & $I$ & & 一 & & 一 & - & - & - & $一$ & $1 \cdot 02$ & $2 \cdot 04^{*}$ & 0.77 & $x \cdot 54^{*}$ \\
\hline \multicolumn{2}{|c|}{ Total weight on } & $3 \cdot 47$ & - & $3 \cdot 27$ & 一 & $5 \cdot 96$ & - & 6.59 & 一 & 8.72 & 一 & $7 \cdot 97$ & - \\
\hline
\end{tabular}
low-Ca diet

* Estimated (egg broken). 
body during the low-Ca period could be calculated. As approximately $98 \%$ of the body $\mathrm{Ca}$ of pullets is present in the bones (Halnan, r936; Common, 1938) and since the amount of $\mathrm{Ca}$ finally present in the skeleton was determined, the percentage loss of skeletal $\mathrm{Ca}$ in this period could also be calculated. The percentage loss of $\mathbf{P}$ from the skeleton could not be calculated in this way as $20 \%$ or so of the body P is present in the soft tissues, nor could it be assumed that the ovaries contained the same amount of vitellin and phospholipid $\mathrm{P}$ at the end of the low-Ca period as at the beginning. In addition, the birds were gaining weight during the experiment. The amount of $P$ originally present in the skeletons can be calculated indirectly, however, on the assumption that their $\mathrm{Ca}: \mathrm{P}$ ratios at the beginning of the low-Ca régime were the same as in the two control birds, which were respectively $2 \cdot 19$ and $2 \cdot 18$. Using the mean of these figures the percentage loss of $\mathrm{P}$ during the low-Ca period can be estimated. Data on the skeletal loss of $\mathrm{Ca}$ and $\mathbf{P}$ are presented in Table 2.

The percentage loss of $\mathbf{P}$ from the skeleton was in all birds slightly less than the percentage loss of $\mathrm{Ca}$. With the exception of bird 7 , the calculated loss of skeletal $\mathrm{P}$ was greater than the negative balance, which means that not all of the $P$ lost from the bones was excreted and it must presumably have been stored in the soft tissues. With birds $\mathrm{I}$ and 2 which laid six eggs on the deficient diet the difference between the amount of $P$ calculated to have been lost from the skeleton and that excreted in eggs and droppings amounted to over I $\mathrm{g}$. Even if the $\mathrm{Ca}: \mathrm{P}$ ratio of the skeletons of these birds at the beginning of the low-Ca period had been $2 \cdot 25$ instead of $2 \cdot 18$, the calculated loss of skeletal $\mathrm{P}$ would have been $0.80 \mathrm{~g}$ and $0.75 \mathrm{~g}$ greater than the negative $\mathrm{P}$ balance for birds $I$ and 2 respectively.

Ash weights of individual bones. Mineral depletion can most usefully be studied by comparing the total amount of ash present in individual bones. As the experimental birds differed somewhat in both live weight and skeletal weight a common basis of comparison was necessary and the standard chosen was a dry, fat-free skeleton weighing roo $\mathrm{g}$ at the time the third egg was laid on the normal-Ca diet when the control birds were killed and the low-Ca régime began. The controls had, respectively, 23.6 and $23.8 \% \mathrm{Ca}$ in their skeletons and the mean of these figures was taken as the $\mathrm{Ca}$ percentage of the skeletons of the other birds at the end of the normal-Ca period. Using this figure their standard skeleton weights at the end of the normal-Ca period were calculated, as the weight of $\mathrm{Ca}$ present at this time could be deduced from the balance and slaughter data.

The mean ash weights for the bones of the two birds on each treatment, corrected to the standard skeletal weight, are given in Table 4 , together with the ash weights of bones from depleted birds expressed as a percentage of the ash weights of the controls.

It will be observed that the loss of minerals from the skeleton was far from uniform. Initially the ilium, ischium and pubis, ribs, femur and fibula suffered the greatest depletion with the thoracic and coccygeal vertebrae and the sternum losing only slightly less. During the calcification of the second two eggs on the low-Ca diet the tibia, coracoid, coccygeal vertebrae and wing bones showed the greatest percentage loss of ash, but the bones that were most severely depleted earlier (with the exception 
of the coccygeal vertebrae) did not suffer much further loss at this stage. A much more generalized loss of minerals took place during the calcification of the fifth and sixth eggs, almost all bones having made some contribution; the cervical and lumbosacral vertebrae, scapula, coracoid, clavicle and sternum lost particularly heavily. The bones that suffered the greatest overall percentage loss were the ribs, sternum, ilium, ischium and pubis, coccygeal vertebrae and fibula, all of which lost at least $50 \%$ of the minerals originally present, with the ribs and sternum having lost approximately $60 \%$.

Table 4. Mean ash weights $(g)$ of the bones of the birds in each treatment corrected to the standard skeletal weight* $(A)$ and mean ash weights of the bones of depleted birds expressed as a percentage of the ash weights of the control birds $(B)$

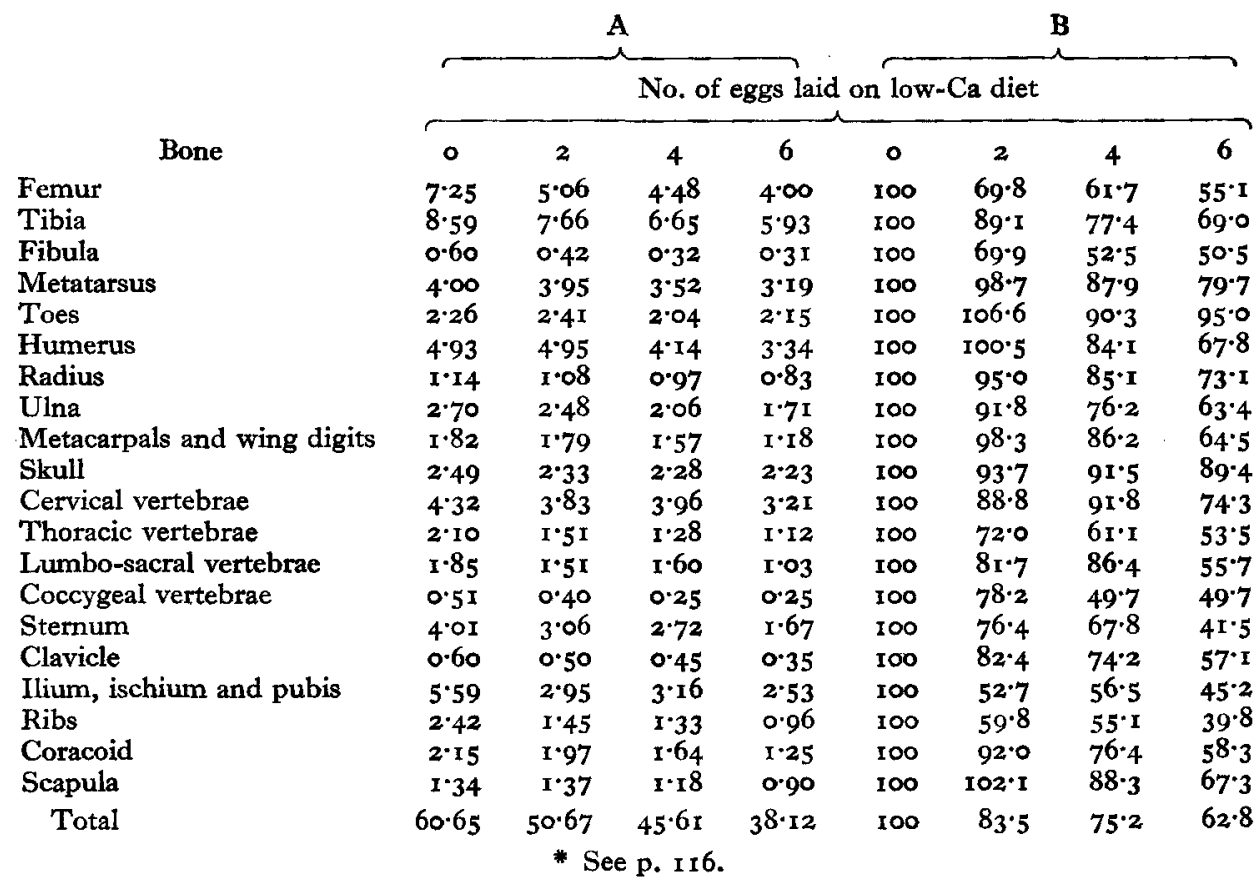

The bones that most successfully maintained their integrity were the skull and the toes, in which mineral losses were negligible. The cervical and lumbo-sacral vertebrae were not appreciably affected until more than four eggs had been laid.

It is interesting to observe which bones were responsible for providing the greatest absolute amounts of minerals during the different stages of skeletal depletion. The percentage contribution of the individual bones is given in Table 5. The femur, ilium, ischium and pubis together supplied almost $50 \%$ of the minerals for the calcification of the first two eggs, with the tibia, ribs and sternum each having contributed over $9 \%$. During the period when the third and fourth eggs were calcified the tibia, humerus and femur gave up the greatest amounts, and in the final stage the sternum made the greatest contribution, while a large number of different bones supplied from 5 to $10 \%$ of the total. Over $50 \%$ of the total mineral matter released from the skeleton for the 
calcification of the six eggs was supplied by the tibia, femur, sternum, ilium, ischium and pubis together.

Medullary bone. The amount of medullary bone present in the skeletons of the experimental birds was surprisingly large. Previous workers (Bloom et al. I94I; Kyes \& Potter, 1934) have reported its presence exclusively in the long bones of the legs, except for Zondek (1936) who found it also in the vertebral column of young cockerels after treatment with oestrogen. In the pullets used in this experiment it was found in all bones, although the skull, humerus, metacarpals, wing digits, metatarsus and toes contained only small amounts (Taylor \& Moore, 1953). Particularly large amounts were present in the sternum, ribs, ilium, ischium and pubis. The percentage of medullary bone in the individual bones of four birds (one from each treatment) are

Table 5. Mean ash losses for individual bones expressed as a percentage of total skeletal loss at each stage of skeletal depletion

\begin{tabular}{|c|c|c|c|c|}
\hline \multirow[b]{2}{*}{ Bone } & \multicolumn{4}{|c|}{$\begin{array}{l}\text { Stage of depletion induced by the laying on the } \\
\text { low-Ca diet of the }\end{array}$} \\
\hline & $\begin{array}{l}\text { First two } \\
\text { eggs }\end{array}$ & $\begin{array}{l}\text { Second two } \\
\text { eggs }\end{array}$ & $\begin{array}{l}\text { Third two } \\
\text { eggs }\end{array}$ & $\begin{array}{l}\text { All six } \\
\text { eggs }\end{array}$ \\
\hline Femur & $2 I \cdot 5$ & I0.6 & 6.3 & 14.4 \\
\hline Tibia & $9 \cdot 2$ & $18 \cdot 2$ & 9.5 & I $1 \cdot 8$ \\
\hline Fibula & $\mathrm{I} \cdot 8$ & $\mathrm{I} \cdot 9$ & $0 \cdot 2$ & $I \cdot 3$ \\
\hline Metatarsus & 0.5 & $7 \cdot 9$ & $4 \cdot 3$ & $3 \cdot 6$ \\
\hline Toes & - & $6 \cdot 7$ & - & 0.5 \\
\hline Humerus & - & $14 \cdot 6$ & $10 \cdot 6$ & $7 \cdot 0$ \\
\hline Radius & 0.6 & $2 \cdot 1$ & $x \cdot 8$ & $1 \cdot 4$ \\
\hline Ulna & $2 \cdot 2$ & $7 \cdot 7$ & 4.5 & 4.4 \\
\hline Metacarpals and wing digits & 0.3 & $4^{\circ} \circ$ & $5 \cdot 2$ & $2 \cdot 9$ \\
\hline Skull & $1 \cdot 6$ & $1 \cdot 0$ & 0.7 & $\mathbf{I} \cdot \mathbf{2}$ \\
\hline Cervical vertebrae & $4 \cdot 7$ & - & 10.0 & $4 \cdot 9$ \\
\hline Thoracic vertebrae & $5 \cdot 8$ & $4 \cdot 1$ & $2 \cdot \mathbf{I}$ & $4: 3$ \\
\hline Lumbo-sacral vertebrae & $3 \cdot 3$ & - & $7 \cdot 5$ & $3 \cdot 6$ \\
\hline Coccygeal vertebrae & $I \cdot 0$ & $2 \cdot 6$ & - & $\mathbf{I} \cdot \mathbf{I}$ \\
\hline Sternum & $9 \cdot 3$ & $6 \cdot 3$ & $13 \cdot 9$ & $10 \% 4$ \\
\hline Clavicle & $I \cdot I$ & $I \cdot O$ & $I \cdot 4$ & $I \cdot 2$ \\
\hline Ilium, ischium and pubis & $26 \cdot 0$ & - & $8 \cdot 3$ & $13 \cdot 6$ \\
\hline Ribs & $9 \cdot 6$ & $2 \cdot \mathbf{I}$ & $4 \cdot 9$ & $6 \cdot 5$ \\
\hline Coracoid & $1 \cdot 7$ & $6 \cdot 1$ & $5 \cdot \mathbf{I}$ & $4 \cdot 0$ \\
\hline Scapula & - & $3 \cdot 4$ & 37 & $1 \cdot 9$ \\
\hline Total & $100 \cdot 2$ & $100 \cdot 2$ & $100 \cdot 0$ & 100.0 \\
\hline
\end{tabular}

given in Table 6. The effect of laying on a low-Ca diet was to increase the proportion of medullary bone, the birds that laid six eggs on this diet having almost twice as much medullary bone, when expressed as a percentage of total bone weight, as the controls. There was, however, a tendency for the medullary bone to be less highly calcified as skeletal depletion advanced, but in spite of the fact that all birds were killed at the same stage of the laying cycle there was a considerable variation in its ash percentage quite unrelated to treatment, as can be seen from Table 7 , which shows the ash percentage of medullary bone from the tibiae, femora, and entire skeleton of the eight pullets. The figures for total medullary ash weight, corrected to standard skeletal weight (Table 8), convey most clearly the effect of the low-Ca diet, and although the amounts are somewhat variable, there appears to be a tendency for the level of 
medullary ash to be maintained in spite of a drastic fall in the amount of cortical ash. This observation was not unexpected in view of the accepted function of medullary bone to act as a readily available source of $\mathrm{Ca}$ for the egg shell, particularly when dietary sources are inadequate.

Table 6. Percentage of medullary bone in individual bones of one bird from each treatment

(Dry, fat-free basis)

\begin{tabular}{|c|c|c|c|c|}
\hline \multicolumn{5}{|c|}{ (Dry, fat-free basis) } \\
\hline & \multicolumn{4}{|c|}{ No. of eggs laid on low-Ca diet } \\
\hline Bone & $\begin{array}{c}0 \\
\text { Bird } \\
\text { no. } 3\end{array}$ & $\begin{array}{c}2 \\
\text { Bird } \\
\text { no. } 5\end{array}$ & $\begin{array}{c}{ }^{4} \\
\text { Bird } \\
\text { no. } 4\end{array}$ & $\begin{array}{c}6 \\
\text { Bird } \\
\text { no. I }\end{array}$ \\
\hline Femur & $2 I \cdot 8$ & $32 \cdot 8$ & $33 \cdot 8$ & $39 \cdot x$ \\
\hline Tibia & $12 * 4$ & I3.I & 19.7 & $34 \cdot 5$ \\
\hline Fibula & $7 \cdot 9$ & I9.0 & $11 \cdot 9$ & $24 \cdot 5$ \\
\hline Metatarsus & $5 \cdot 1$ & $3 \cdot 6$ & $2 \cdot 7$ & $4 \cdot 5$ \\
\hline Toes & $1 \cdot 3$ & 40 & $x \cdot 6$ & $2 \cdot 8$ \\
\hline Humerus & 4.6 & $6 \cdot 8$ & $8 \cdot 6$ & 14.7 \\
\hline Radius & $3 \cdot 6$ & $3 \cdot 6$ & $8 \cdot 4$ & $7 \cdot 9$ \\
\hline Ulna & 4.0 & 6.7 & $10 \cdot 6$ & $23 \cdot 9$ \\
\hline Metacarpals and wing digits & $4 \cdot 3$ & $6 \cdot 5$ & $4 \cdot 5$ & $17 \cdot 9$ \\
\hline Skull & $7 \cdot 2$ & $8 \cdot 3$ & $2 \cdot 0$ & $7 \cdot 5$ \\
\hline Cervical vertebrae & $7 \cdot 0$ & 10.0 & $9 \cdot 0$ & $13^{\circ} 9$ \\
\hline Thoracic vertebrae & $10: 3$ & $15 \cdot 9$ & $22 \cdot 6$ & $31 \cdot 7$ \\
\hline Lumbo-sacral vertebrae & 6.7 & $21 \cdot 8$ & 30.1 & $16 \cdot 3$ \\
\hline Coccygeal vertebrae & $20 \cdot 5$ & $16 \cdot 0$ & 34.0 & $56 \cdot 8$ \\
\hline Sternum & 15.5 & $18 \cdot 3$ & 20.8 & $28 \cdot 7$ \\
\hline Clavicle & $12 \cdot 2$ & 14.7 & $14 \cdot 5$ & 16.0 \\
\hline Ilium, ischium and pubis & 20.8 & $32 \cdot 0$ & 27.4 & 36.5 \\
\hline Ribs & $29 \cdot 2$ & 39.9 & $39 \cdot 8$ & $51 \cdot 8$ \\
\hline Coracoid & $3 \cdot 7$ & 10.3 & 13.8 & $21 \cdot 3$ \\
\hline Scapula & $16 \cdot 1$ & $9 \cdot 8$ & $14^{*} 1$ & 147 \\
\hline Total skeleton & II 7 & $15 \cdot 0$ & $16 \cdot 6$ & $23 \cdot 6$ \\
\hline
\end{tabular}

Table 7. Percentage ash in medullary bone from tibiae and femora and from the entire skeletons of all the birds

No. of eggs laid on low-Ca diet

$\overbrace{\text { Bird Bird }}^{0} \overbrace{\text { Bird Bird }}^{2} \overbrace{\text { Bird Bird }}^{4} \overbrace{\text { Bird Bird }}^{6}$

$\begin{array}{llllllllllllll} & & 38 \cdot 3 & 48 \cdot 8 & 43 \cdot 6 & 40 \cdot 6 & 17 \cdot 4 & 29 \cdot 0 & 43 \cdot 6 & 49 \cdot 1 & 46 \cdot 3 & 28 \cdot 0 & 17 \cdot 8 & 22 \cdot 9 \\ \text { Femora } & 4 \mathrm{I} \cdot \mathrm{I} & 48 \cdot 8 & 45 \cdot 0 & 46 \cdot 9 & 17 \cdot 4 & 32 \cdot 2 & 36 \cdot 4 & 4 \mathrm{I} \cdot 8 & 39 \cdot \mathrm{I} & 30 \cdot 7 & \mathbf{1 7} \cdot 8 & 24 \cdot 3\end{array}$

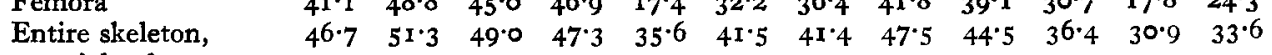

weighted mean

* Bone from tibiae and femora bulked for analysis.

Ash percentage in cortical bone. Ash-percentage figures for some of the bones that suffered the most severe mineral depletion (as shown by total ash weights) are compared in Table 9 with figures for those that suffered least. With the exception of the femur there was a tendency for the bones subject to severe depletion to have a lower ash percentage as the degree of depletion became more extreme, but the reduction was not great and might well have been due to contamination of the cortical bone with non-osseous organic matter (particularly with haematopoietic tissue) or with medullary 
bone. Reduction in ash percentage due to contamination of this nature would become increasingly great with increasing loss of total ash, and it is perhaps significant that the femur, in which contamination was unlikely to be great, did not show a consistent fall in ash percentage with increasing severity of depletion.

Table 8. Effect of laying on a low-calcium diet on the amount of medullary bone and medullary bone ash of all the birds

No. of eggs laid on low-Ca diet

$\overbrace{\text { Bird Bird }}^{\circ} \overbrace{\text { Bird Bird }}^{2} \overbrace{\text { Bird Bird }}^{4} \overbrace{\text { Bird Bird }}^{6}$

Variable studied

Medullary bone expressed as percentage of total skeletal weight

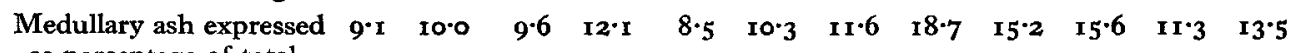
as percentage of total ash

Total medullary ash corrected to standard skeletal weight $(\mathrm{g})$

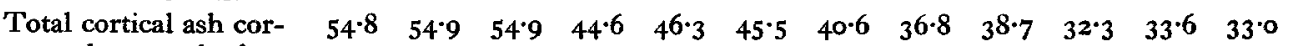
rected to standard skeletal weight $(g)$

no. 3 no. 8 Mean no. 5 no. 7 Mean no. 4 no. 6 Mean no. I no. 2 Mean

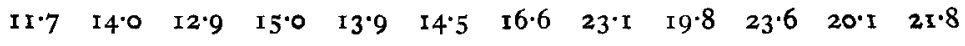

$\begin{array}{llllllllllll}5.47 & 6.09 & 5.78 & 6.16 & 4.31 & 5.24 & 5.37 & 8.45 & 6.91 & 6.00 & 4.28 & 5.14\end{array}$

Table 9. Ash percentage of bones that suffered the most severe mineral depletion and of those that suffered least

No. of eggs laid on low-Ca diet

\begin{tabular}{|c|c|c|c|c|c|c|c|c|c|c|c|c|}
\hline \multirow[b]{3}{*}{ Bone } & \multicolumn{12}{|c|}{ No. of eggs laid on low-Ca diet } \\
\hline & \multicolumn{3}{|c|}{ o } & \multicolumn{3}{|c|}{2} & \multicolumn{3}{|c|}{4} & \multicolumn{3}{|c|}{6} \\
\hline & $\begin{array}{l}\text { Bird } \\
\text { no. } 3\end{array}$ & $\begin{array}{c}\text { Bird } \\
\text { no. } 8\end{array}$ & Mean & $\begin{array}{l}\text { Bird } \\
\text { no. } 5 \\
\text { Most d }\end{array}$ & $\begin{array}{l}\text { Bird } \\
\text { no. } 7 \\
\text { epletio }\end{array}$ & $\begin{array}{l}\text { Mean } \\
\text { on }\end{array}$ & $\begin{array}{l}\text { Bird } \\
\text { no. } 4\end{array}$ & $\begin{array}{l}\text { Bird } \\
\text { no. } 6\end{array}$ & Mean & $\begin{array}{l}\text { Bird } \\
\text { no. I }\end{array}$ & $\begin{array}{l}\text { Bird } \\
\text { no. } 2\end{array}$ & Mean \\
\hline Ribs* & $60 \cdot 4$ & $6 \pi \cdot 7$ & $6 I \cdot I$ & $60 \cdot 0$ & $6 I \cdot 4$ & $60 \cdot 7$ & $60 \cdot 3$ & $60 \cdot 3$ & $60 \cdot 3$ & $57^{\circ} 0$ & $57^{\circ} \mathrm{I}$ & $57^{\cdot I}$ \\
\hline Sternum* & $60 \cdot 4$ & $6 r \cdot 7$ & $6 r \cdot r$ & $59 \cdot 3$ & $6 I \cdot 4$ & 60.4 & $59 \div 7$ & $60 \cdot 6$ & $60 \cdot 2$ & $57 \cdot 7$ & $57 \cdot 1$ & $57 \cdot 4$ \\
\hline $\begin{array}{l}\text { Ilium, ischium and } \\
\text { pubis }\end{array}$ & $59 \cdot \mathrm{I}$ & $61 \cdot 7$ & $60 \cdot 4$ & $60 \cdot 8$ & $6 I \cdot 4$ & $6 \mathrm{I} \cdot \mathrm{I}$ & $58 \cdot 5$ & $5^{8 \cdot 8}$ & $58 \cdot 7$ & $56 \cdot 9$ & $57 \cdot I$ & $57 \cdot 0$ \\
\hline $\begin{array}{l}\text { Thoracic vertebrae } \\
\text { Femur }\end{array}$ & $\begin{array}{l}59 \cdot 7 \\
68 \cdot 9\end{array}$ & $\begin{array}{l}58 \cdot 6 \\
67 \cdot 1\end{array}$ & $\begin{array}{l}59 \cdot 2 \\
68 \cdot 0\end{array}$ & $\begin{array}{l}58 \cdot x \\
65 \cdot 9\end{array}$ & $\begin{array}{l}60 \cdot 0 \\
68 \cdot 0\end{array}$ & $\begin{array}{l}59 \cdot 1 \\
67 \cdot 0\end{array}$ & $\begin{array}{l}59 \cdot 2 \\
66 \cdot 9\end{array}$ & $\begin{array}{l}59 \cdot 7 \\
65 \cdot 6\end{array}$ & $\begin{array}{l}59 \cdot 5 \\
66 \cdot 3\end{array}$ & $\begin{array}{l}55 \cdot 9 \\
67 \cdot 9\end{array}$ & $\begin{array}{l}55 \cdot 9 \\
68 \cdot 8\end{array}$ & $\begin{array}{l}55^{\circ} 9 \\
68 \cdot 4\end{array}$ \\
\hline \multicolumn{13}{|c|}{ Least depletion } \\
\hline Skull & $60 \cdot 5$ & $58 \cdot 6$ & $59 \cdot 6$ & $56 \cdot 3$ & $60 \cdot 0$ & $58 \cdot 1$ & $59 \cdot 5$ & 59.7 & $59 \cdot 6$ & $6 r \cdot 6$ & $6 I \cdot 6$ & $6 I \cdot 6$ \\
\hline $\begin{array}{l}\text { Metatarsus } \\
\text { Radius }\end{array}$ & $\begin{array}{l}59 \cdot 9 \\
62 \cdot 3\end{array}$ & $\begin{array}{l}57 \cdot 3 \\
63 \cdot 8\end{array}$ & $\begin{array}{l}58 \cdot 6 \\
62 \cdot 1\end{array}$ & $\begin{array}{l}58 \cdot 2 \\
62 \cdot 4\end{array}$ & $\begin{array}{l}57 \cdot 8 \\
63 \cdot 0\end{array}$ & $\begin{array}{l}58 \cdot 0 \\
62 \cdot 7\end{array}$ & $\begin{array}{l}6 x \cdot 6 \\
63 \cdot 8\end{array}$ & $\begin{array}{l}6 x \cdot 6 \\
65 \cdot 7\end{array}$ & $\begin{array}{l}6 r \cdot 6 \\
64 \cdot 8\end{array}$ & $\begin{array}{l}59 \cdot 4 \\
6 \mathrm{r} \cdot 6\end{array}$ & $\begin{array}{l}58 \cdot 8 \\
63 \cdot 4\end{array}$ & $\begin{array}{l}59 \cdot 1 \\
62 \cdot 5\end{array}$ \\
\hline $\begin{array}{l}\text { Entire skeleton, } \\
\text { weighted mean }\end{array}$ & $62 \cdot 1$ & $62 \cdot 4$ & $62 \cdot 3$ & $60 \cdot 4$ & $6 I \cdot 9$ & $6 I \cdot 2$ & $6 \mathrm{I} \cdot 5$ & $62 \cdot 0$ & $6 x \cdot 8$ & $60 \cdot 4$ & $6 I \cdot I$ & 60.8 \\
\hline
\end{tabular}

Composition of bone ash. Weighted mean figures for the percentages of $\mathrm{Ca}$ and $\mathrm{P}$ in the ash of medullary and cortical bone, together with the corresponding $\mathrm{Ca}: \mathrm{P}$ ratios are given in Table ro. In general, medullary ash had slightly less $\mathrm{Ca}$ and more $\mathrm{P}$ than cortical ash and, as might be expected, depletion of the body of Ca resulted in the ash of both medullary and cortical bone becoming richer in $\mathrm{P}$ and poorer in $\mathrm{Ca}$. In 
Table II the Ca:P ratios of cortical bone from severely depleted bones are compared with those of bones that suffered only slightly, and it is clear from these figures that a Ca-rich fraction of bone mineral was removed during the course of the skeletal depletion, leaving behind a mineral with a $\mathrm{Ca}: \mathrm{P}$ ratio that became progressively lower with increasing severity of depletion. It is interesting to observe that although the skull, metatarsus and toes lost quite small amounts of ash, their $\mathrm{Ca}: \mathrm{P}$ ratios followed the same trend as those for the bones that suffered severely.

Table 10. Composition of cortical and medullary bone ash (weighted means) of all the birds

No. of eggs laid on low-Ca diet

Percentage of $\mathrm{Ca}$ Individual birds

\begin{tabular}{|c|c|c|c|c|c|c|c|}
\hline \multicolumn{4}{|c|}{ Ash of cortical bone } & \multicolumn{4}{|c|}{ Ash of medullary bone } \\
\hline 0 & 2 & 4 & 6 & 0 & 2 & 4 & 6 \\
\hline $\begin{array}{l}39 \cdot 2 \\
39 \cdot 1\end{array}$ & $\begin{array}{l}39 \cdot 8 \\
38 \cdot 9\end{array}$ & $\begin{array}{l}39 \cdot 2 \\
38 \cdot 9\end{array}$ & $\begin{array}{l}38 \cdot 5 \\
38 \cdot 8\end{array}$ & $\begin{array}{l}38 \cdot 6 \\
38 \cdot 2\end{array}$ & $\begin{array}{l}38 \cdot 4 \\
37 \cdot 1\end{array}$ & $\begin{array}{l}38 \cdot 1 \\
38 \cdot 3\end{array}$ & $\begin{array}{l}36 \cdot 4 \\
36 \cdot 5\end{array}$ \\
\hline $39 \cdot 2$ & $39 \cdot 4$ & $39^{\cdot} I$ & $38 \cdot 7$ & $38 \cdot 4$ & $37 \cdot 8$ & $38 \cdot 2$ & $36 \cdot 5$ \\
\hline $\begin{array}{r}17.9 \\
17.9\end{array}$ & $\begin{array}{l}18 \cdot 2 \\
18 \cdot 1\end{array}$ & $\begin{array}{l}18.0 \\
18.2\end{array}$ & $\begin{array}{l}18 \cdot 3 \\
18 \cdot 4\end{array}$ & $\begin{array}{l}17 \cdot 9 \\
17 \cdot 6\end{array}$ & $\begin{array}{l}18 \cdot 1 \\
18 \cdot 4\end{array}$ & $\begin{array}{l}18 \cdot 4 \\
18 \cdot 3\end{array}$ & $\begin{array}{l}18 \cdot 6 \\
18 \cdot 9\end{array}$ \\
\hline 17.9 & $18 \cdot 2$ & $18 \cdot 1$ & I 8.4 & $\mathrm{r} 7 \cdot 8$ & I $8 \cdot 3$ & $18 \cdot 4$ & 18.8 \\
\hline $2 \cdot 19$ & $2 \cdot 19$ & $2 \cdot 18$ & $2 \cdot 10$ & $2 \cdot 15$ & $2 \cdot 13$ & $2 \cdot 07$ & 1.90 \\
\hline & $2 \cdot 15$ & $2 \cdot 13$ & $2 \cdot I I$ & $2 \cdot 16$ & $2 \cdot 02$ & $2 \cdot 10$ & $2 \cdot 04$ \\
\hline $2 \cdot 19$ & $2 \cdot 17$ & $2 \cdot 16$ & $2 \cdot 11$ & $2 \cdot 16$ & 2.08 & $2 \cdot 09$ & 2.00 \\
\hline
\end{tabular}

Table II. Ca:P ratios of cortical bone ash from bones that suffered the most severe mineral depletion and from those that suffered least, for all the birds

\begin{tabular}{|c|c|c|c|c|c|c|c|c|c|c|c|c|}
\hline \multirow[b]{3}{*}{ Bone } & \multicolumn{12}{|c|}{ No. of eggs laid on low-Ca diet } \\
\hline & \multicolumn{3}{|c|}{$\circ$} & \multicolumn{3}{|c|}{2} & \multicolumn{3}{|c|}{4} & \multicolumn{3}{|c|}{6} \\
\hline & $\begin{array}{c}\text { Bird } \\
\text { no. } 3\end{array}$ & $\begin{array}{l}\text { Bird } \\
\text { no. } 8\end{array}$ & Mean & $\begin{array}{l}\text { Bird } \\
\text { no. } 5 \\
\text { Most d }\end{array}$ & $\begin{array}{c}\text { Bird } \\
\text { no. } 7 \\
\text { epletio }\end{array}$ & $\begin{array}{l}\text { Mean } \\
\mathbf{n}\end{array}$ & $\begin{array}{c}\text { Bird } \\
\text { no. } 4\end{array}$ & $\begin{array}{r}\text { Bird } \\
\text { no. } 6\end{array}$ & Mean & $\begin{array}{l}\text { Bird } \\
\text { no. I }\end{array}$ & $\begin{array}{c}\text { Bird } \\
\text { no. } 2\end{array}$ & Mean \\
\hline Ribs & $2 \cdot 18$ & $2 \cdot 18$ & $2 \cdot 18$ & $2 \cdot 12$ & 2.II & $2 \cdot 12$ & $2 \cdot 10$ & $2 \cdot I I$ & 2. I I & $\mathrm{I} \cdot 98$ & $2 \cdot 04$ & $2 \cdot 01$ \\
\hline Sternum & $2 \cdot 17$ & $2 \cdot 18$ & $2 \cdot 18$ & $2 \cdot 17$ & $2 \cdot 11$ & $2 \cdot 14$ & $2 \cdot 16$ & $2 \cdot 10$ & $2 \cdot 13$ & $2 \cdot 02$ & $2 \cdot 04$ & $2 \cdot 03$ \\
\hline Ilium, ischium, pubis & $2 \cdot 17$ & $2 \cdot 18$ & $2 \cdot 18$ & $2 \cdot 16$ & $2 \cdot 11$ & $2 \cdot 14$ & $2 \cdot 10$ & $2 \cdot 08$ & $2 \cdot 09$ & $x \cdot 98$ & $2 \cdot 04$ & 2+or \\
\hline \multicolumn{13}{|c|}{ Least depletion } \\
\hline Skull & $2 \cdot 18$ & $2 \cdot 17$ & $2 \cdot 18$ & $2 \cdot 17$ & $2 \cdot 14$ & $2 \cdot 16$ & $2 \cdot 20$ & $2 \cdot 13$ & $2 \cdot 17$ & $2 \cdot I I$ & $2 \cdot 08$ & $2 \cdot 10$ \\
\hline Metatarsus & $2 \cdot 22$ & $2 \cdot 23$ & $2 \cdot 23$ & $2 \cdot 22$ & $2 * 19$ & $2 \cdot 21$ & $2 \cdot 23$ & $2 \cdot 20$ & $2 \cdot 22$ & $2 \cdot 17$ & $2 \cdot 16$ & $2 \cdot 17$ \\
\hline Toes & $2 \cdot 24$ & $2 \cdot 23$ & $2 \cdot 23$ & $2 \cdot 25$ & $2 \cdot 23$ & $2 \cdot 24$ & $2 \cdot 22$ & $2 \cdot 20$ & $2 \cdot 21$ & $2 \cdot 17$ & $2 \cdot 20$ & $2 \cdot 19$ \\
\hline
\end{tabular}

Table 12 gives the $\mathrm{Ca}: \mathrm{P}$ ratios of medullary bone from the tibiae and femora, obtained quite uncontaminated with cortical bone. Apart from bird no. 7 which was exceptional, having both low total ash and low $\mathrm{Ca}: \mathrm{P}$ ratio, the fall in $\mathrm{Ca}: \mathrm{P}$ ratio was not marked until six eggs had been laid on the Ca-deficient diet.

\section{DISCUSSION}

During the pre-laying period all eight pullets retained minerals with a $\mathrm{Ca}: \mathrm{P}$ ratio much higher than that of normal bone, and Common (1933, 1936, 1938) observed the same phenomenon in some of his birds when a high-Ca ration (approx. $2 \% \mathrm{Ca}$ ) was fed, but not on a low-Ca ration $(0 \cdot 26 \% \mathrm{Ca})$. A satisfactory explanation for these findings 
has yet to be put forward. It has been suggested that the new bone laid down during this period might have a higher $\mathrm{Ca}: \mathrm{P}$ ratio than normal bone, but in view of the finding that the mineral composition of both medullary and cortical bone from the control birds in the present experiment was normal, this possibility appears to be most unlikely.

A second possible explanation is that during the pre-laying period the $\mathrm{Ca}: \mathrm{P}$ ratio of the whole skeleton increases considerably. Using the mean weights of $\mathrm{Ca}$ and $\mathrm{P}$ found to have been stored during the pre-laying period in the present experiment and assuming that an average skeleton contains $24.3 \mathrm{~g} \mathrm{Ca}$ and $10.8 \mathrm{~g} \mathrm{P}$ at the end of this period, it can be calculated that the $\mathrm{Ca}: \mathrm{P}$ ratio would have to change from $\mathrm{I} \cdot 97$ to 2.25. A change of this magnitude in less than a fortnight is difficult to conceive, but in view of the observed $\mathrm{Ca}: \mathrm{P}$ ratios of 2.08 and 2.09 found for the complete skeletons of birds I and 2 after they had laid six eggs on the low-Ca diet, compared with control values of $2 \cdot 18$ and $2 \cdot 19$, this possibility cannot be dismissed. Unfortunately there is no reliable method of calculating the $\mathrm{Ca}: \mathrm{P}$ ratios of the skeletons of our experimental

Table 12. Ca:P ratios of medullary bone from tibiae and femora for all the birds

\begin{tabular}{|c|c|c|c|c|c|c|c|c|c|c|c|c|}
\hline \multirow[b]{3}{*}{ Bone } & \multicolumn{12}{|c|}{ No. of eggs laid on low-Ca diet } \\
\hline & \multicolumn{3}{|c|}{0} & \multicolumn{3}{|c|}{2} & \multicolumn{3}{|c|}{4} & \multicolumn{3}{|c|}{6} \\
\hline & $\begin{array}{l}\text { Bird } \\
\text { no. } 3\end{array}$ & $\begin{array}{l}\text { Bird } \\
\text { no. } 8\end{array}$ & Mean & $\begin{array}{l}\text { Bird } \\
\text { no. } 5\end{array}$ & $\begin{array}{c}\text { Bird } \\
\text { no. } 7\end{array}$ & Mean & $\begin{array}{c}\text { Bird } \\
\text { no. } 4\end{array}$ & $\begin{array}{r}\text { Bird } \\
\text { no. } 6\end{array}$ & Mean & $\begin{array}{l}\text { Bird } \\
\text { no. I }\end{array}$ & $\begin{array}{l}\text { Bird } \\
\text { no. } 2\end{array}$ & Mean \\
\hline Tibiae & $2 \cdot 11$ & - & - & $2 \cdot 06$ & - & - & $2 \cdot 10$ & $2 \cdot 10$ & $2 \cdot 10$ & I.9I & - & - \\
\hline Femora & $2 \cdot 13$ & - & - & 2.II & - & 一 & $2 \cdot 04$ & $2 \cdot 09$ & $2 \cdot 07$ & I.93 & - & - \\
\hline Mean for both bones & $2 \cdot 12$ & $2 \cdot 16^{*}$ & $2 \cdot 14$ & $2 \cdot 09$ & $x \cdot 79^{*}$ & $\mathbf{I} \cdot 94$ & $2 \cdot 07$ & $2 \cdot 10$ & $2 \cdot 09$ & $1 \cdot 92$ & $x \cdot 76^{*}$ & $I \cdot 84$ \\
\hline $\begin{array}{c}\mathrm{Ca} \text { in last egg on } \\
\text { low-Ca diet } \%\end{array}$ & - & - & - & $3 \cdot 84$ & $3 \cdot 42$ & - & $2 \cdot 50$ & $2 \cdot 96$ & - & $2 \cdot 04$ & $1 \cdot 54$ & 一 \\
\hline
\end{tabular}

birds before and after pre-laying storage as both skeletal and soft-tissue metabolism contribute to the observed $\mathrm{P}$ balances.

A third possibility is that $P$ from extra-skeletal sources is available for bone mineralization at this time, a suggestion tentatively put forward by Common (I938) and which is perhaps strengthened by the observation that $\mathrm{P}$ appears to have been retained in the soft tissues of the pullets that were laying on a $\mathrm{Ca}$-deficient diet in the present experiment. Further work is in progress to investigate the whole question of pre-laying storage and of the possible storage of $\mathrm{P}$ in the soft tissues.

As a result of histological studies (McLean \& Bloom, 1940; Bloom et al. 1941) it has been suggested that the removal of minerals from the skeleton can occur in vivo only as a result of bone resorption, in which both organic matrix and mineral matter are removed together. If this view is correct loss of minerals should not bring about a reduction in ash percentage, and the results of the present investigation tend to support it. The mean ash content of the femora of the six-egg birds that had lost $45 \%$ of their mineral matter was actually higher than that of the controls. If, however, the progressive reduction in ash percentage observed in the ribs, sternum, ilium, ischium and pubis with increasing severity of depletion was in fact due to demineralization and not to the presence of non-osseous organic matter, it could have taken place only 
to a limited extent, as a loss in total ash of over $50 \%$ was in these bones associated with a reduction in ash percentage of little more than $5 \%$.

Sobel, Rockenmacher \& Kramer (I945), in an experiment in which groups of rats were fed on rations deficient in $\mathrm{Ca}, \mathrm{P}$, or both, have shown that the composition of bone mineral is related to the composition of the blood serum from which it is precipitated, and it seems likely that the blood picture of the hens on the Ca-deficient diet was not unlike that of the rats of the low-Ca, high-P treatment. If this was so, the low Ca:P ratios of the medullary bone from birds $I, 2$ and 7 were reflexions of low diffusible $\mathrm{Ca}$, high inorganic phosphate and low bicarbonate levels in the blood induced by egg laying on the Ca-deficient ration. Similarly, the fact that the Ca:P ratios of the medullary bone of the birds that laid two and four eggs on the low-Ca diet were not in general greatly depressed, suggests that these birds were fairly successful in maintaining the diffusible $\mathrm{Ca}$ level in their blood, a suggestion which is strengthened by the fact that these birds were still capable of laying eggs with reasonably good shells. The ash content of the medullary bone from birds 2 and 7 was very low (mean $17.63 \%$ ) and the extremely low Ca: $\mathrm{P}$ ratio of this bone might be due in part to the presence of considerable amounts of organically combined $P$.

The two birds that laid six eggs on the deficient ration each lost over $38 \%$ of the total skeletal $\mathrm{Ca}$ initially present, one in 10 and the other in 12 days, a severity of depletion quite remarkable in such a short time. Common's (1938) low-Ca birds lost $24 \%$ of their skeletal $\mathrm{Ca}$, one after laying eleven eggs in 40 days and the other after laying thirteen eggs in 69 days, but his ration contained $0.260 \% \mathrm{Ca}$ compared with $0.054 \%$ in the present experiment. Whereas Common's birds were laying soft-shelled eggs at the time they were killed, the final eggs laid by birds $I$ and 2 of the present experiment were by no means soft-shelled, so that it seems probable that a still higher degree of depletion could have been achieved. The fact that the total medullary bone of birds $\mathrm{I}$ and 2 contained respectively $2 \cdot \mathrm{I} 7$ and $\mathrm{I} \cdot 43 \mathrm{~g}$ of $\mathrm{Ca}$ at slaughter is further evidence that calcification of the egg-shell was still possible.

After birds $\mathrm{x}$ and 2 had laid six eggs on a Ca-deficient diet their complete skeletons had $\mathrm{Ca}: \mathrm{P}$ ratios of $2 \cdot 08$ and $2 \cdot 09$ respectively, compared with values of $2 \cdot 18$ and $2 \cdot 19$ for the controls. From the balance data and bone analysis (Table 2) it has been calculated that the $\mathrm{Ca}: \mathrm{P}$ ratios of the mineral matter lost during the low-Ca régime were $2 \cdot 38$ and $2 \cdot 35$ respectively. It appears therefore that the bones of laying pullets are capable of losing $\mathrm{Ca}$ and $\mathrm{P}$ at a higher $\mathrm{Ca}: \mathrm{P}$ ratio than normal bone, as Tyler (1940) had already inferred from balance experiments. A detailed chemical study of the changes taking place during skeletal depletion is in progress.

\section{SUMMARY}

I. Using balance and slaughter techniques the effects of progressive mineral depletion on the skeletons of pullets have been studied by allowing them to lay no, two, four or six eggs on a calcium-deficient diet. During the pre-laying period and up to the time the third egg was laid the birds were maintained on a high ( $1.9 \%) \mathrm{Ca}$ ration. 
2. The mean weights of $\mathrm{Ca}$ and phosphorus stored by the eight pullets during the pre-laying period were $5 \cdot 58$ and $\mathrm{I} \cdot 3 \mathrm{I} \mathrm{g}$ respectively, giving a mean $\mathrm{Ca}: \mathrm{P}$ ratio of $4 \cdot 25$.

3. There was a reduction in the percentage of shell $\mathrm{Ca}$ when the birds were placed on the low-Ca diet. The reduction became progressively greater with each egg laid.

4. After the laying of two, four or six eggs on the deficient diet the mean skeletal losses of Ca were $16 \cdot 3,25 \cdot 2$ and $38 \cdot 4 \%$ respectively. The percentage loss of $P$ was in all birds slightly less than the percentage loss of $\mathrm{Ca}$.

5. During the low-Ca period five out of six birds excreted less $P$ than was calculated to have been lost from the skeleton. This $\mathrm{P}$, which amounted to over $\mathrm{I} g$ in the birds that had laid six eggs on the deficient diet, is thought to have been stored in the soft tissues.

6. The mean ash weights of individual bones from the two birds on each of the low-Ca treatments were compared with controls. The bones that suffered the greatest proportional losses were the ribs, sternum, ilium, ischium and pubis, coccygeal vertebrae, and fibula, all of which, in the birds that had laid six eggs on the deficient ration, lost over $50 \%$ of the mineral matter originally present. The bones that suffered least were the skull, metatarsus and toes.

7. The level of medullary bone ash tended to be maintained during the low-Ca régime in spite of a severe fall in the amount of cortical ash.

8. The percentage of ash in the depleted bones showed a slight reduction in most birds.

9. Severely depleted bones showed a much greater reduction in the $\mathrm{Ca}: \mathrm{P}$ ratio than those bones that had suffered only slightly.

Io. The significance of the high $\mathrm{Ca}: \mathrm{P}$ ratio of the mineral stored in the pre-laying period and of the changes in bone composition consequent on mineral depletion is discussed.

\section{REFERENCES}

Benoit, J. \& Clavert, J. (1945). C.R. Soc. Biol., Paris, 139, 737.

Bloom, W., Bloom, M. A. \& McLean, F. C. (I941). Anat. Rec. 8r, 443.

Bloom, W. \& Domm, L. V. (194I). Anat. Rec. 8r, 91 (Suppl.)

Common, R. H. (1933). F. agric. Sci. 23, 555.

Common, R. H. (1936). F. agric. Sci. 26, 85 .

Common, R. H. (1938). f. agric. Sci. 28, 347.

Deobald, H. J., Lease, E. J., Hart, E. B. \& Halpin, J. G. (1936). Poult. Sci. 15, 179.

Gerritz, H. W. (1935). Industr. Engng Chem. (Anal.), 7, 167.

Halnan, E. 'T, (r936). World's Poult. Congr. vi. Berlin, $\mathbf{1}, 53$.

Kitson, R. E. \& Mellon, M. G. (1944). Industr. Engng Chem. (Anal.), 16, 379.

Koenig, R. A. \& Johnson, C. R. (1942). Industr. Engng Chem. (Anal.), 14, 155.

Kyes, P. \& Potter, T. S. (1934). Anat. Rec. 60, 377.

McLean, F. C. \& Bloom, W. (r940). Anat. Rec. 78, 333 .

Morgan, C. L., Mitchell, J. H., Ringrose, R. C. \& Lease, E. J. (1942). Poult. Sci. $21,212$.

Sobel, A. E., Rockenmacher, M. \& Kramer, B. (1945). F. biol. Chem. 159, 59.

Taylor, T. G. \& Moore, J. H. (1953). Nature, Lond., 172, 504.

Tyler, C. (1940). Biochem. F. 34, 202.

Wheatley, V. R. (1944). Analyst, 69, 207.

Zondek, B. (1936). Lancet, 231, 842 . 